\title{
Root and Soil-borne Oomycetes (Heterokontophyta) and Fungi Associated with the Endangered Conifer, Torreya taxifolia Arn. (Taxaceae) in Georgia and Florida, USA $^{1}$
}

\author{
Lydia I. Rivera Vargas ${ }^{2}$ and Vivian Negron-Ortiz ${ }^{3}$
}

\begin{abstract}
A systematic survey was conducted to isolate and identify root and soil-borne oomycetes and fungi associated with the rare and endangered southeastern USA conifer, Torreya taxifolia Arn. Twenty four trees showing different degrees of decline were sampled at two different sites: Torreya State Park, Liberty County, Florida $(\mathrm{n}=12)$ and US Corps of Engineers in Decatur, Georgia $(\mathrm{n}=$ 12). All T. taxifolia trees sampled showed moderate to severe levels of decline (100\% decline incidence) based on criteria, such as poor development of trees, stunting and fragility. Disease severity was higher, and trees were smaller with poor development at Florida sites, showing an average height of $89 \mathrm{~cm}$, and a diameter at breast height $(\mathrm{DBH})$ of $5 \mathrm{~cm}$ compared to trees in Georgia's site (174 cm h and $10.6 \mathrm{~cm}$ DBH in average) In addition to decline, root necrosis and stem cankers were observed in $45.8 \%$ of trees examined. A diverse fungal community was associated with declining trees. Twenty eight fungal genera were identified belonging to the Oomycetes, Zygomycetes, Ascomycetes, Basidiomycetes and anamorphic fungi. Anamorphic fungi, Oomycetes, and Zygomycetes were the dominant groups associated with T. taxifolia. Pestalotiopsis spp., Fusarium spp. and Pythium spp. were the most common genera. Most isolates were obtained from root tissue. Seventy four percent $(74 \%)$ of isolates were from samples collected at a Georgia site. Alternaria spp., Cylindrocladium sp., Fusarium spp., Phoma sp., Pythium spp., Rhizoctonia sp., Thielaviopsis sp. and Verticillium sp. are among soil-borne oomycetes and fungal species identified. Not known Phytophthora spp. were isolated during the survey. Interactions of oomycetes and fungi inhabiting the soil and rhizosphere could play an important role in T. taxifolia's decline.
\end{abstract}

Key Words: Torreya taxifolia, endangered species, soil-borne pathogens, Oomycetes, Fungi

Torreya taxifolia Arn. (family Taxaceae), commonly known as Florida torreya or 'stinking yew', is a dioecious evergreen coniferous tree. Branches are whorled with needle-like leaves of pungent, resinous odor (USFWS 1986). Florida Torreya is endemic to the ravine slopes on the eastern bank of the Apalachicola River in northern Florida and in parts of Georgia. Prior to 1950's, T. taxifolia was estimated to be the seventh most abundant tree species within Apalachicola Bluff regions (Schwartz et al., 1995). Surveys conducted in areas

\footnotetext{
${ }^{1}$ Submitted on October 23, 2013Accepted on November 12, 2013. Final revision received on December 11, 2013. The genus Torreya has also been recently placed in the Cephalotaxaceae although recent studies seem to favor a placement in a more broadly defined Taxaceae (Christenhusz et al. 2011).

${ }^{2}$ Professor, Department of Crops and Agro-Environmental Sciences, P.O. Box 9000, University of Puerto Rico-Mayagüez Campus, Mayagüez, PR 00681. Corresponding author: E-mail s: lydiai.rivera@upr.edu

3 Botanist, U.S. Fish and Wildlife Service, 1609 Balboa Ave. Panama City, Florida 32405 and Department of Biology, Miami University, Oxford, Ohio 45056 USA. E-mail: vivian_negronortiz@fws.gov
}

DOI: 10.9784/LEB1(4)RiveraVargas.03

Electronically available on December 31, 2013. Mailed on December 28, 2013. 
with known high tree densities suggested that T. taxifolia has lost at least $98.5 \%$ of its total population size since the early 1900s, causing the species to be federally listed as endangered in 1984 (USFWS 1986). Current populations are characterized by small $(<2 \mathrm{~m}$ tall) individuals that are failing to achieve reproductive maturity. Most of the wild population persists as stump sprouts; only three seed bearing adult female trees have been reported from the wild. In addition, the plants exhibit slow growth (Spector, pers. comm.). Given the lack of seed production in the wild, and potentially a decline due to a disease, all models seem to predict eventual extinction (Schwartz and Herman 1993).

The loss of $T$. taxifolia is thought to have been a result of oomycetes and fungal pathogens during the 1950's and 1960's, and/or a combination of environmental stress and native pathogens, but studies have yet to provide an explanation for this species' decline. Broad studies addressing abiotic hypotheses, in which historical observations, as well as physiological and growth responses to several environmental factors were examined, showed little supportive evidence that $T$. taxifolia was subjected to environmental stress (Schwartz et al. 1995). Studies addressing biotic factors have focused mainly on pathogens causing needle spots, blights, and stem cankers (Table 1) (Alfieri 1984, El-Gholl 1985, USFWS 1986, Alfieri et al. 1987, Farr et al. 1989, Schwartz et al. 1996, Herman and Schwartz 1997, Mount and Smith 2010, Smith et al. 2011). Important soil-borne pathogens, such as Phytophthora sp., Pythium sp., Rhizoctonia solani Kühn and Sclerotium rolfsii Sacc. have been reported associated with $T$. taxifolia, but their role in Torreya's decline has not been addressed (Alfieri et al. 1984). Soil-borne oomycetes such as Phytophthora spp. are potentially devastating pathogens causing serious damage to many trees species in a variety of ecosystems worldwide. Phytophthora spp. have been implicated as one of the responsible factors in T. taxifolia's population decline in Georgia, but species identification and pathogenicity has not been not investigated. In Florida, P. cinnamomi Rands has been associated with disease outbreaks in sand pines, and has been indirectly associated with $T$. taxifolia's root rot (Alfieri et al. 1984, Barnard et al. 1985). Unfortunately, none of these studies provided a conclusive explanation for the species' decline based on virulence of a oomycete species. Overall, very few studies have addressed root or soil-borne pathogens. Therefore, oomycetes species associated with root tissue and with other trees in its ecosystem need to be examined. Recently, a newly described species, Phytophthora ramorum (Werres, De Cock, and Man in't Veld), has caused widespread and sudden death of oak trees in California (Rizzo et al. 2002). In Southwestern Oregon, various Phytophthora spp. have been regarded as the causal agent of Tanoak (Lithocarpus densiflorus (Hook. and Arn.) Rehder) stem cankers (Reeser et al. 2008).

In addition to Phytophthora spp., another oomycetes, Pythium spp. are known to cause post-emergence damping-off of seedlings of coniferous trees. Various species of Pythium have been isolated from soil in forest nurseries in 
the Southeastern United States: P. irregulare-debaryanum, P. sylvaticum W.A. Campb. and F.F. Hendrix, $P$. spinosum Sawada, $P$. helicoides Drechsler and $P$. splendens Hans Braun (Hendrix and Campbell 1973). These species caused reduction of root and shoot systems, due to feeder root necrosis in surviving seedlings. Plant susceptibility to feeder root necrosis varied with the species of Pythium examined. Pathogenicity of Pythium spp. has been demonstrated in pine seedlings in Japan, where Pythium ultimum Trow and P. aphanidermatum (Edson) Fitzp were the most virulent (Watanabe 1988). In South Africa, root rot of seedlings have been associated with $P$. ultimum and damping-off with $P$. irregulare Buisman (Viljoen et al. 1992). In nature, non-pathogenic Pythium species usually coexist with pathogenic ones (Viljoen et al. 1992).

Table 1. Fungi previously reported associated with Torreya spp.

\begin{tabular}{|c|c|c|}
\hline Species of Fungi & Symptoms & References \\
\hline Alternaria sp. & needle spot & Alfieri et al. 1984 \\
\hline Botrysophaeria sp. & needle spot & $\begin{array}{l}\text { Alfieri et al. 1984, } \\
\text { Mount and Smith } \\
2009\end{array}$ \\
\hline $\begin{array}{l}\text { Caeoma torreyae Bonar, } \\
1951\end{array}$ & rust & Farr et al. 1995 \\
\hline Diaporthe sp. & associated to cankers & $\begin{array}{l}\text { Mount and Smith } \\
2010\end{array}$ \\
\hline $\begin{array}{l}\text { Diplodia natalensis Pole- } \\
\text { Evans, } 1911\end{array}$ & twig dieback & Alfieri et al. 1984 \\
\hline Fusarium sp. & root rot associated to cankers & $\begin{array}{l}\text { Alfieri et al. 1984, } \\
\text { Mount and Smith } \\
2010\end{array}$ \\
\hline $\begin{array}{l}\text { Fusarium torreyae Aoki, } \\
\text { Smith, Mount, Geiser, and } \\
\text { O'Donnell, } 2013\end{array}$ & canker & $\begin{array}{l}\text { Smith et al. } 2011 \text {, } \\
\text { Aoki et al. } 2013\end{array}$ \\
\hline $\begin{array}{l}\text { Fusarium lateritium Nees, } \\
1817\end{array}$ & needle spot & $\begin{array}{l}\text { El-Gholl 1985, } \\
\text { Alfieri et al. } 1987\end{array}$ \\
\hline Hypoxylon sp. & associated to cankers & $\begin{array}{l}\text { Mount and Smith } \\
2010\end{array}$ \\
\hline $\begin{array}{l}\text { Janetia bonarii (M. B. Ellis) } \\
\text { S. Hughes, } 1983\end{array}$ & associated to needles & Farr et al. 1995 \\
\hline Macrophoma sp. & needle and stem blight & Alfieri et al. 1984 \\
\hline $\begin{array}{l}\text { Lasiodiplodia theobromae } \\
\text { (Pat., 1892) Griffon and } \\
\text { Maulb., 1909 }\end{array}$ & associated to cankers & $\begin{array}{l}\text { Mount and Smith } \\
2010\end{array}$ \\
\hline $\begin{array}{l}\text { Pestalotiopsis microspora } \\
\text { (Speg. , 1880) G. C. Zhao } \\
\text { and N. Li, 1995 }\end{array}$ & needle spots and stem cankers & Schwartz et al. 1996 \\
\hline Phomopsis sp. & associated to cankers & $\begin{array}{l}\text { Mount and Smith } \\
2010\end{array}$ \\
\hline
\end{tabular}


Table 1. Fungi previously reported associated with Torreya spp. (continuation)

\begin{tabular}{|l|l|l|}
\hline Species of Fungi & Symptoms & References \\
\hline Phyllosticta sp. $^{2}$ & needle spot & Alfieri et al. 1987 \\
\hline Physalospora sp. & needle stem and twig blight & Alfieri et al. 1987 \\
\hline $\begin{array}{l}\text { Phytophthora cinnamomi } \\
\text { Rands, 1922 }\end{array}$ & root rot & Alfieri et al. 1984 \\
\hline Pythium sp. & root rot & Alfieri et al. 1984 \\
\hline $\begin{array}{l}\text { Rhizoctonia solani } \text { Kühn, } \\
1858\end{array}$ & root rot & Alfieri et al. 1984 \\
\hline $\begin{array}{l}\text { Sclerotium rolfsii } \text { Sacc., } \\
\text { 1911 }\end{array}$ & southern blight & Alfieri et al. 1984 \\
\hline Scytalidium sp. & needle spot and necrosis & $\begin{array}{l}\text { Hermann and } \\
\text { Schwartz 1997 }\end{array}$ \\
\hline Sphaeropsis sp. & needle blight & Alfieri et al. 1984 \\
\hline $\begin{array}{l}\text { Sporidesmium fragilissimum } \\
\text { (Berk and M.A. Curtis,1875) } \\
\text { M. B. Ellis, 1958 }\end{array}$ & associated needles & Farr et al. 1995 \\
\hline $\begin{array}{l}\text { Xylocoremium flabelliforme } \\
\text { (Schwein., 1797) J. D. } \\
\text { Rogers, } 1984\end{array}$ & $\begin{array}{l}\text { associated to needles and } \\
\text { stems }\end{array}$ & Alfieri et al. 1987 \\
\hline
\end{tabular}

${ }^{1}$ Current name Botryosphaeria rhodina (Berk. and M. A. Curtis) Arx,, 1970

${ }^{2}$ Phyllosticta sp., imperfect stage of Guignardia sp.

${ }^{3}$ Xylocoremium flabelliforme is the imperfect stage of Xylaria cubensis (Mont.) Fr.

Worldwide, Fusarium spp. are frequently associated with root diseases although species differ in pathogenicity, and in host specificity (Alfieri et al. 1984, Viljoen et al. 1992, Leslie and Summerell 2006). Fusarium spp. chlamydospores infect the roots and ramify through the root system, affecting both cortical and vascular tissues (Agrios 2005). Young seedling infections are usually lethal. In older seedlings infection causes root rot, and death of growing tips. Bark and cortex of infected roots are usually exposed due to infection. Several Fusarium species have been shown pathogenic to $T$. taxifolia, by causing needle spots, i.e. F. lateritium Nees (El-Gholl 1985, Alfieri et al. 1987), and has been associated with root rot (Alfieri et al. 1984). More recently, a novel described species F. torreyae Aoki, Smith, Mount, Geiser, and O'Donnell, was demonstrated to be the causal agent of stem cankers (Smith et al. 2011). Until now, none Fusarium spp. has been demonstrated to cause cankers comparable to those observed in the field. In other conifer species, F. oxysporum Schltdl. Emend. Snyder and Hansen has been associated with seedling death and root rot (Viljoen et al. 1992).

Other soil-borne pathogens such as Calonectria spp. (anamorph Cylindrocladium spp.), Rhizoctonia solani, Thielaviopsis spp. and Verticillium 
sp. have been associated with root diseases in conifers. For example, Rhizoctonia solani caused damping-off and root rot of Pinus seedlings in forest nurseries in South Africa (Viljoen et al. 1992). It survives in the soil by the production of sclerotia that germinates and invades seedlings' roots, stems and leaves. Calonectria spp. are important plant pathogens associated with forestry crops in temperate, subtropical and tropical climates (Lombard et al. 2009; Lombard et al., 2010). In forest trees, symptoms includes cutting rot, dampingoff, leaf spots, shoot blight, stem cankers, and root diseases (Lombard et al., 2010). In Brazil, seven Pinus spp. were wound-inoculated with C. brassicae (Pamwar and Bohra) L. Lombard, M. J. Wingf., and Crous, resulting in mortality of all tested plants within two weeks. They concluded that the pathogen was highly virulent in established plantations of Pinus spp. (Hodges and May 1972). Thielaviopsis pp. is also a common and important soil-borne pathogen of many agricultural crops (Agrios 2005). Symptoms associated with this plant disease are damping off and root rot. Infected plants are usually stunted and chlorotic, with a characteristic black root rot. The dark colored areas are produced by chlamydospores, which are thick walled spores produced in chains in infected root tissues.

Currently, there have been no systematic studies of soil-borne pathogens associated with $T$. taxifolia and with other trees in its surrounding ecosystem. Therefore, a systematic soil survey was conducted in Florida and Georgia, emphasizing the detection of oomycetes.

\section{Systematic survey of soil-borne fungi \\ Methods}

A systematic survey was conducted in which samples from roots, soil and plant litter associated with $T$. taxifolia were collected from three sites at Torreya State Park, Florida, and one site in Decatur, Georgia. Samples were collected from trees showing decline symptoms (Figure 1). A composed soil sample was taken with a stainless steel $(1.5 \times 14 \mathrm{~cm})$ soil probe in a circle mode around each tree between the drip line and the base of the tree. Two soil samples opposite from each other were collected from each tree and placed in a plastic bag. The soil top layer $(10 \mathrm{~mm})$ including plant litter was collected in a separate plastic bag. The soil probe was wiped off of all organic matter (i.e. soil and plant litter) with a clean paper tissue. Plastic gloves were used and changed through sample recollection process. Using a small garden shovel, soil was removed to exposed feeder roots that showed decay (necrosis) or were colonized by mycelium. These were collected and placed in plastic bags. Equipment used (soil probe and garden shovel) was sterilized on site using $95 \%$ ethanol and rinsed with sterilized distilled water to reduce contamination between sampling sites (Inglis and Hill 2007).

A total of 24 trees were sampled, twelve from each state which is a sizable proportion of the remaining known population. Diameter at breast height (DBH 
in $\mathrm{cm}$ ), height $(\mathrm{cm})$ and GPS coodinates were taken for each tree. Tree health or decline (feeder root necrosis, stem cankers, mycelium development on tree base or on cortex, dying branches and dying trees) was also recorded. In addition, disease severity was estimated based on percentage of healthy to severe decline of trees as follow: healthy trees or no decline $=\mathrm{O}, \mathrm{L}=$ low symptoms ranging from 1 to $25 \%$ of decline, $M=$ moderate symptoms ranging from 26 to $50 \%$ of decline and $\mathrm{S}=$ severe symptoms higher than $51 \%$ of decline.

\section{Isolation and identification of soil-borne pathogens associated to $T$. taxifolia and its surrounding ecosystem}

\section{Fungal isolation methods}

To isolate soil-borne fungi, serial dilutions of soil samples, plant tissue baits or traps, and direct pathogen isolation from host tissue (roots and plant litter surrounding tree base) were used emphasizing the detection of oomycetes such as Phytophthora spp. and Pythium spp. (Mitchell and Kannwischer-Mitchell 1992, Martin 1992). Commonly used culture media were prepared to isolate fungi and included acidified Potato Dextrose Agar (PDA), carnation leaf agar (CLA), Phytophthora selective media known as PARP-V8 and PARP with $T$. taxifolia needles (Jeffers and Martin 1986). The last medium contains selective antibiotics and fungicides. Isolation media were kept refrigerated.

\section{Soil serial dilutions}

Ten grams of soil were used for serial dilutions (i.e. $10^{-2}, 10^{-4}, 10^{-6}$ ). One hundred microliters from each dilution were transferred and spread to PARP-V8 culture media (Martin 1992). Plates were incubated at $26^{\circ} \mathrm{C}$. Colonies development was examined daily.

\section{Baiting bioassays}

Baiting bioassays using Camelia and Torreya leaves were used to detect soil-borne fungi and oomycetes (Ferguson and Jeffers 1999). Plates were made using fresh soil samples and plant litter surrounding tree's base. Plant litter and soil samples were placed in sterile Petri plates $(60 \times 15 \mathrm{~mm})$ and were covered with sterile de-ionized distilled water. Three leaf baits or traps were placed per plate containing either flooded plant litter or soil sample (Ferguson and Jeffers 1999). Hyphal growth on bait leaf margins was examined after 24, 48 and $72 \mathrm{~h}$ at room temperature and was isolated in PARP media. Colonies were purified and kept in PARP-V8 at $4^{\circ} \mathrm{C}$ in the dark.

\section{Direct isolation from fresh plant material}

Sections of root samples were cleaned with running tap water for half hour. Root sections were transferred directly to culture media: PDA and PARP-V8 media (Mitchell and Kannwischer-Mitchell 1992, Martin 1992). Plates were 
kept at room temperature for colonies' development. Colonies were purified and identified. Also, mycelium observed under stereoscope growing on plant litter (bark and leaves) were directly transferred to culture media.

\section{Fungal Identification: Morphology, ELISA and DNA analysis}

Oomycetes reproductive structures such as sporangia, oogonium and antheridia, coenocitic hyphae, and hyphal swellings produced on PARP or PDA media were examined under light microscopy. Fungal reproductive structures such as conidia, conidiophores and mycelium produced on PDA media were examined under light microscopy. Reproductive structures were photographed and recorded. Taxonomic keys were used for identification (Barnett and Hunter 1998, Boerema et al. 2004, Hanlin 1990, Leslie and Summerell 2006, Gallegly and Hong 2008, van der Plaats-Niterink 1981). Other techniques based on immunology such as enzyme-linked immunosorbent assay (ELISA) and DNA analysis were used to complement traditional identification. A commercial Phytophthora ELISA kits (Agdia $\left.{ }^{\circledR}\right)$ was used to complement oomycetes characterization. DNA analysis (i.e. PCR) of a commonly used genetic region for fungal identification such as the internal transcribed spacer (ITS) of the ribosomal DNA (rDNA) (White et al. 1990) was used to complement morphology.

Sixty isolates were selected for DNA analysis. Total genomic DNA was extracted from mycelium using the Qiagen DNeasy Plant Mini Kit (Qiagen Inc., Valencia, California) following manufacturer's instructions. DNA samples were diluted in TE buffer (10mM Tris-HCL; 1mM EDTA) to a concentration of 25 $\mathrm{ng} / \mu \mathrm{l}$ and stored at $-20^{\circ} \mathrm{C}$. PCR was performed using a thermocycler (Perkin Elmer, Model 2400, Wellesley, Massachusetts) with primers ITS1 and ITS4 (White et al. 1990). PCR was performed in a total volume of $50 \mu \mathrm{L}$ containing: $25 \mu$ Amplitaq Gold ${ }^{\circledR}$ PCR Master Mix (Roche, New Jersey USA), 12 pmol of each primer, $17 \mu \mathrm{L}$ of ultra-pure water (Sigma), 20 to $30 \mathrm{ng}$ of DNA. PCR conditions were as follows: $94^{\circ} \mathrm{C}$ for $4 \mathrm{~min}$, followed by 35 cycles of $94^{\circ} \mathrm{C}$ for 2 $\min , 55^{\circ} \mathrm{C}$ for $30 \mathrm{~s}$ and $72^{\circ} \mathrm{C}$ for $1 \mathrm{~min}$, with a final extension at $72^{\circ} \mathrm{C}$ for $4 \mathrm{~min}$ (Konstantinova et al. 2002; White et al. 1990). PCR products were visualized on $1.2 \%$ agarose gel with a UV illuminator (Quantity One® 4.5 2003, Bio-Rad Laboratories, Hercules, CA). PCR products were purified by using QIA quick PCR purification Kit (Qiagen $\AA$, Valencia, California) according to the manufacturer's instructions. DNA was sequenced at the Sequencing and Genotyping Facilities, Department of Biology, University of Puerto Rico, Río Piedras Campus. DNA sequences were edited using BioEdit (version 7.1.9). Codon-based MUSCLE alignment function in Guidance® was used to align ITS rDNA (Penn et al. 2010). DNA sequences were compared with nucleotide data from fungal species of the GenBank National Center for Biotechnology Information (NCBI), using BLAST (http://www.ncbi.nlm.nih.gov/BLAST/). 
Identification of Cytospora sp., Guignardia spp. and Umbellopsis sp. isolates relayed on DNA analysis of the region described above.

Phylogenetic analysis of nucleotide sequences were conducted employing maximum likelihood analysis with the software package MEGA (Molecular Evolutionary Genetics Analysis version 5.2.1) (Tamura et al., 2011). Clade support was assessed by 2000 bootstrap replications of ITS rDNA region. Estimation of nucleotide substitution were made using Tamura Nei Model. Tree inferences were made using the nearest neighborhood interexchange (NNI) heuristic method.

\section{Torreya taxifolia trees assessment}

\section{Results and Discussion}

All T. taxifolia trees sampled showed moderate to severe degrees of decline (100\% decline incidence) based on criteria such as poor development of trees, stunting and fragility (Figure 1, Table 2). In addition, feeder root necrosis and stem cankers were observed in $45.8 \%$ of trees examined (Table 2). Disease severity was higher and trees were smaller with poor development at Florida sites, showing an average height of $89 \mathrm{~cm}$, and an DBH of $5 \mathrm{~cm}$ compared to trees in Georgia's site (174 $\mathrm{cm} \mathrm{h}$ and $10.6 \mathrm{~cm} \mathrm{DBH}$ in average) (Figure 1, Table 2). In Florida sampling sites, soil samples were damped with higher humidity, compared to the soil at the Georgia site. Overall, four trees showed mycelial growth on cortex or on tree base (Figure 1). In Florida, the main trunk of two severe affected trees had cankers at the base of the tree.

\section{Fungal isolates}

A diverse fungal community was identified associated with declining trees (Figures 2 and 3). Composition of fungal community included plant pathogens, lignin and cellulose decomposers, endophytes and saprophytes (Table 3). One hundred and two fungal isolates were obtained from roots, soil and plant litter associated with $T$. taxifolia. Of these 27 isolates $(26 \%)$ were obtained at Torreya State Park and $75(74 \%)$ from Georgia. Twenty eight genera were identified belonging to the oomycetes, zygomycetes, ascomycetes, basidiomycetes and anamorphic fungi. Anamorphic fungi such as Pestalotiopsis and Fusarium; zygomycetes and oomycetes (Pythium spp.) were the dominant taxonomic groups (Figure 3). Most isolates were obtained from root tissue collected at the Georgia site (Table 3).

Thirteen oomycetes (13\%) were isolated from bark, plant litter, roots and baits using Torreya leaf disks (Figure 4). Oomycetes colonies on PARP formed aerial mycelium. Globose intercalary hyphal swellings were abundant on culture media. Oogonia were rarely formed on culture media; but when produced, oogonia were globose surrounded by various antheridia forming a knot, typical of P. heterothallicum (Figure 4C). Most oomycetes were identified as Pythium spp. One of the isolates was obtained from Georgia sampling site using 
Torreya's needles as bait. All oomycetes except for one were isolated from roots of severe affected or dying trees at Torreya State Park. Pythium spp. and an unknown oomycete were isolated from roots of dying specimens at both locations. Along with Oomycetes, Fusarium spp. were one of the most common fungi isolated during this survey and were also commonly isolated from roots of dying trees. Oomycetes were not effective competitors in culture media when more aggressive fungal species such as Fusarium spp. and Mortierella spp. were present, making difficult their isolation.

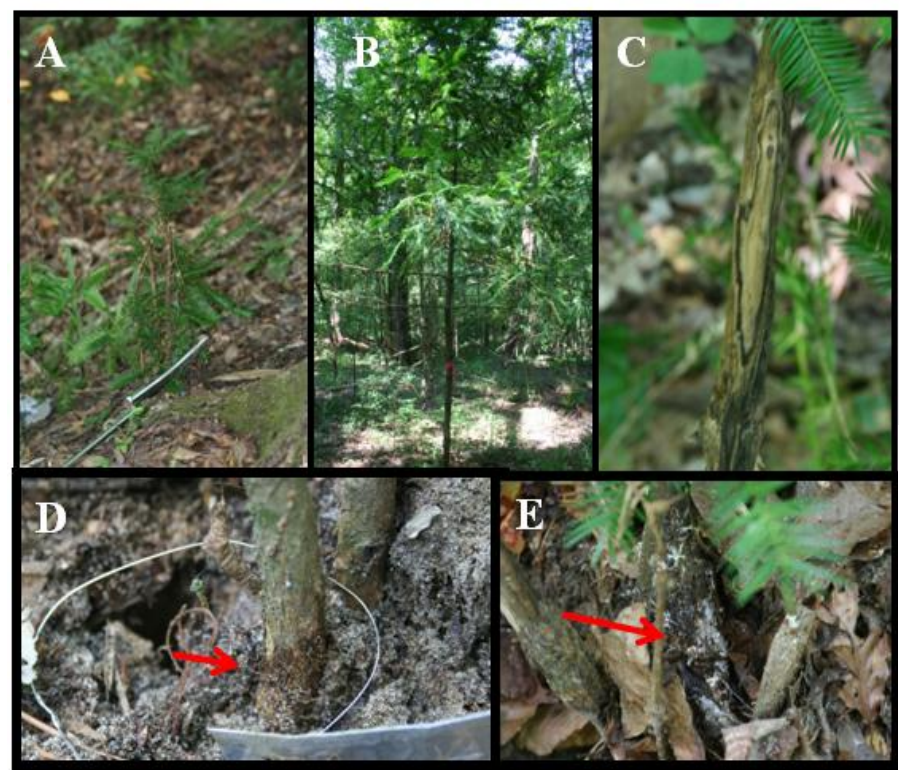

Figure 1. Torreya taxifolia trees from sampling sites: Poor growth and development was observed on trees at A) Torreya State Park, Florida and B) Decatur, Georgia. C. Canker symptoms observed at Torreya State Park. D. Feeder roots (red arrow) and crown base necrosis (dark circular/annular areas at base of tree). E. Mycelial mats (white areas) associated with plant litter surrounding trees.

Soil dilutions and baits using Torreya and Camelia leaves were unsuccessful in the isolation of known Phytophthora spp. Not known Phytophthora species were isolated directly from root samples, based on negative ELISA test specific for Phytophthora spp., even though $P$. cinnamomi had been implicated as one of the responsible factors of T. taxifolia's population decline (Alfieri et al. 1984, Barnard et al. 1985). DNA analysis was inconclusive in identifying oomycetes specimens. Oomycetes species may act as plant pathogens affecting roots or seedlings, and can act as saprophytes. Further studies focusing on the detailed identification of oomycetes associated with Torreya's decline are urgently needed. 


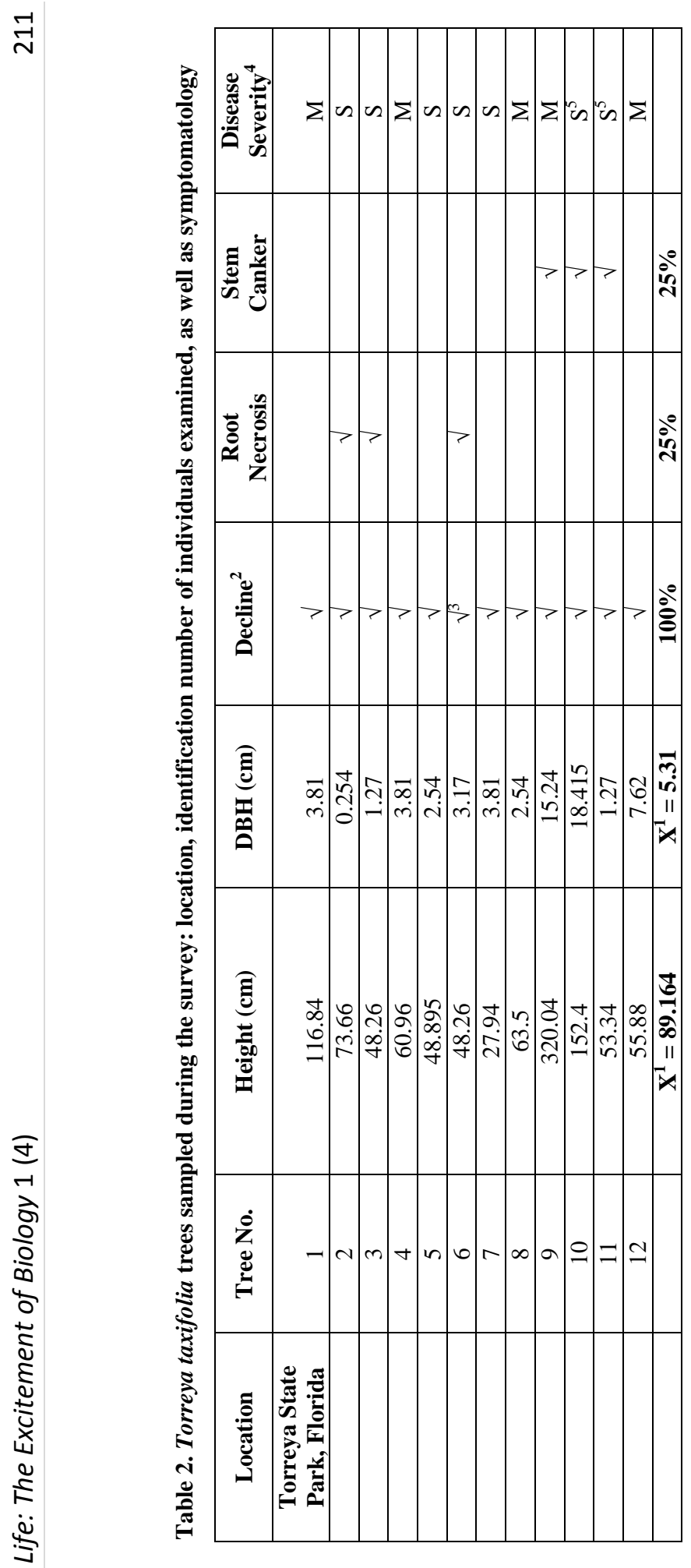




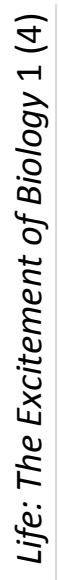

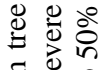

\%

용

言害

웡

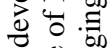

⿷

层

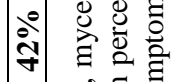

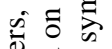

券焉

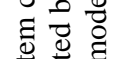

$\therefore$ क⿺

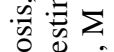

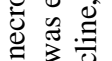

3 过

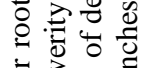

尝

近

4 .

苛 छ

0

产

: 웡

응 茲

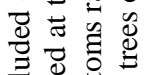

品 虽.

응 ลे

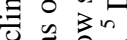

Зั

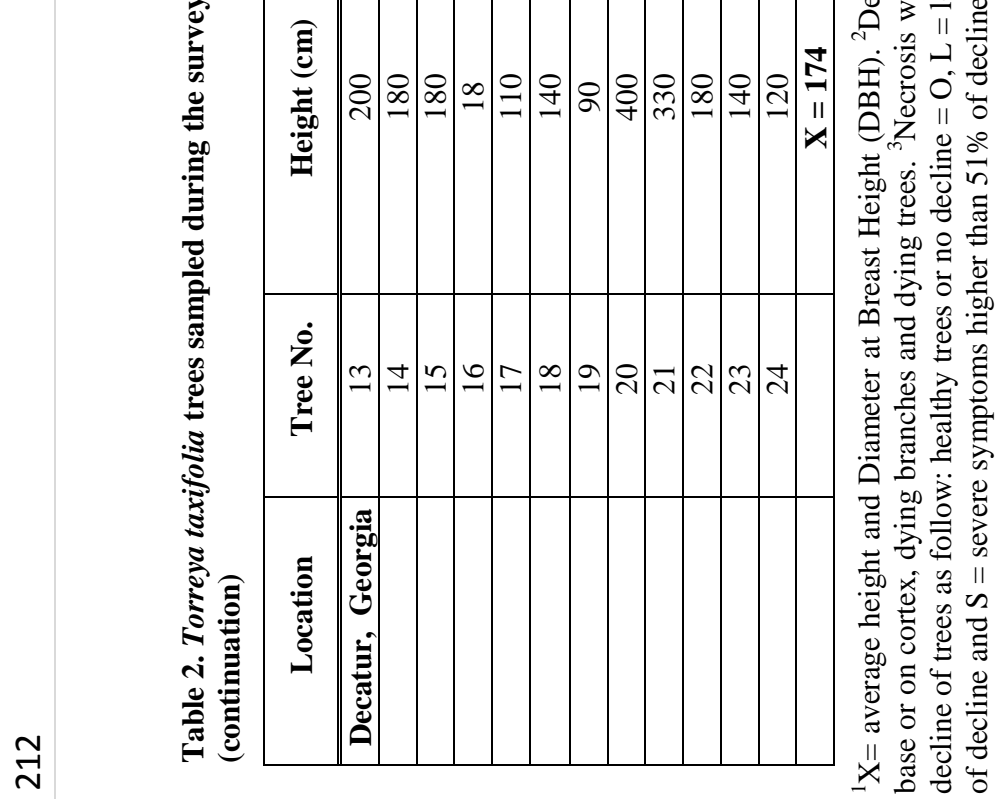




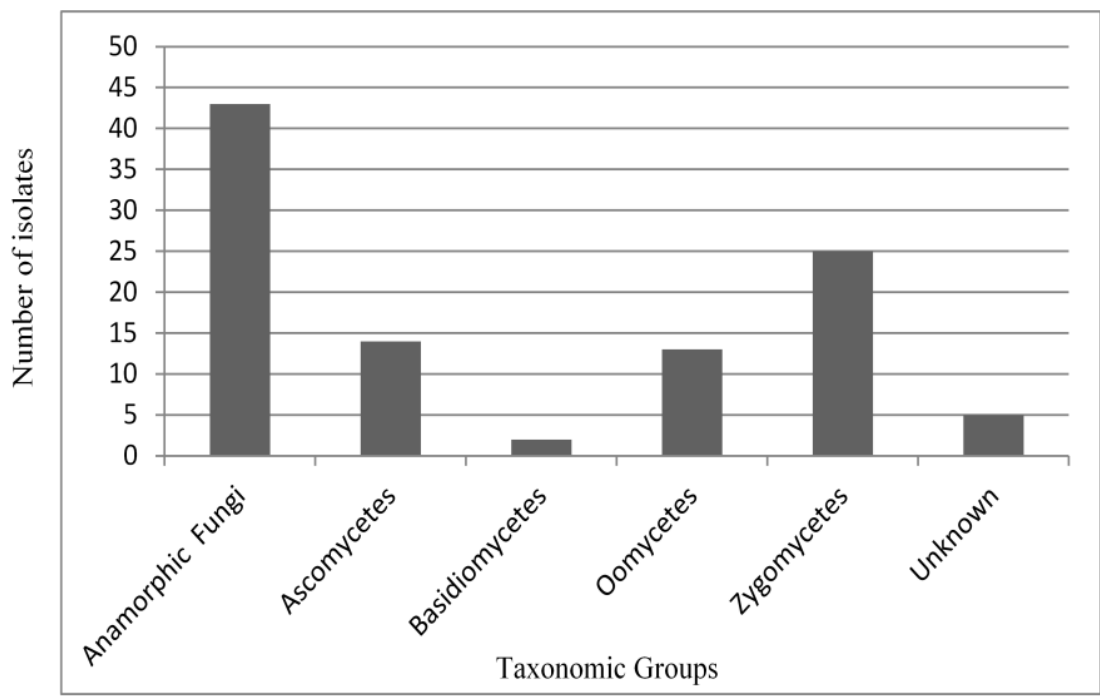

Figure 2. Taxonomic groups of microorganisms isolated from roots, soil, bark and plant litter associated to Torreya taxifolia in sampled sites located at Florida and Georgia, USA.

Table 3. Fungi isolated and identified associated with Torreya taxifolia in this study

\begin{tabular}{|l|l|l|l|}
\hline Fungal Species & Taxonomic Group & $\begin{array}{l}\text { Samples and } \\
\text { Location }\end{array}$ & Habit types \\
\hline Absidia spp. & Zygomycetes & Torreya leaf baits/G & saprophytes \\
\hline Alternaria spp. & Ascomycetes & Roots/G & $\begin{array}{l}\text { saprophytes, foliar } \\
\text { pathogens }\end{array}$ \\
\hline Aspergillus flavus & Ascomycetes & $\begin{array}{l}\text { Torreya leaf baits, } \\
\text { Roots /F and G }\end{array}$ & saprophytes \\
\hline Cephalosporium sp. & Anamorphic Fungi & Roots/F and G & $\begin{array}{l}\text { saprophytes, parasitic } \\
\text { on fungi }\end{array}$ \\
\hline Chaetomium sp. & Ascomycetes & Roots/G & $\begin{array}{l}\text { saprophytes, cellulose } \\
\text { decomposers }\end{array}$ \\
\hline Cladosporium sp. & Anamorphic Fungi & Torreya leaf baits/G & saprophytes \\
\hline Cunninghamella sp. & Zygomycetes & Roots/G & saprophytes \\
\hline Curvularia sp. & Ascomycetes & Roots/F & saprophytes \\
\hline Cylindrocladium sp. & Ascomycetes & Roots/G & plant pathogens \\
\hline Cytospora sp. & Ascomycetes & Roots/G & plant pathogen \\
\hline & & Bark and Leaf Litter, & $\begin{array}{l}\text { saprophytes, } \\
\text { endophytes, plant } \\
\text { pathogens }\end{array}$ \\
\hline Fusarium spp. & Ascomycetes & Roots / F and G & plant pathogens \\
\hline F. oxysporum & Ascomycetes & Leaf litter, Roots/G & plant pathogens \\
\hline F. solani & Ascomycetes & Roots/G &
\end{tabular}


Table 3. Fungi isolated and identified associated with Torreya taxifolia in this study (continuation)

\begin{tabular}{|c|c|c|c|}
\hline Fungal Species & Taxonomic Group & $\begin{array}{l}\text { Samples and } \\
\text { Location }^{1}\end{array}$ & Habit types \\
\hline Guignardia spp. & Ascomycetes & Roots/F and $\mathrm{G}$ & $\begin{array}{l}\text { plant pathogens, } \\
\text { endophytes }\end{array}$ \\
\hline Humicola sp. & Anamorphic Fungi & Roots/G & $\begin{array}{l}\text { saprophytes, parasitic } \\
\text { on fungi }\end{array}$ \\
\hline Mortierella spp. & Zygomycetes & Roots/F and G & saprophytes \\
\hline Mucor spp. & Zygomycetes & $\begin{array}{l}\text { Leaf Litter, Roots/F } \\
\text { and G }\end{array}$ & saprophytes \\
\hline Nigrospora sp. & Anamorphic Fungi & Roots/G & saprophytes \\
\hline Penicillium spp. & Ascomycetes & Roots/G & saprophytes \\
\hline \begin{tabular}{|l|} 
Pestalotiopsis \\
microspora
\end{tabular} & Anamorphic Fungi & $\begin{array}{l}\text { Bark and Leaf litter, } \\
\text { Roots/F and G }\end{array}$ & plant pathogens \\
\hline Phoma sp. & Anamorphic Fungi & Roots/G & $\begin{array}{l}\text { endophytes, } \\
\text { saprophytes, plant } \\
\text { pathogens }\end{array}$ \\
\hline Pythium sp. & Oomycetes & $\begin{array}{l}\text { Bark Litter, Roots, soil } \\
\text { baits/ F and G }\end{array}$ & $\begin{array}{l}\text { plant pathogens, } \\
\text { saprophytes }\end{array}$ \\
\hline \begin{tabular}{|l} 
Pythium \\
heterothallicum
\end{tabular} & Oomycetes & Roots/G & plant pathogens \\
\hline Rhizoctonia sp. & Basidiomycetes & $\begin{array}{l}\text { Bark litter, Roots/G } \\
\text { and F }\end{array}$ & plant pathogens \\
\hline $\begin{array}{l}\text { Schizophyllum } \\
\text { commune }\end{array}$ & Basidiomycetes & Roots/G & $\begin{array}{l}\text { lignin and cellulose } \\
\text { decomposers }\end{array}$ \\
\hline Scytalidium sp. & Anamorphic Fungi & Roots/G & plant pathogen \\
\hline Thielaviopsis sp. & Anamorphic Fungi & Roots/G & plant pathogens \\
\hline Trichoderma sp. & Anamorphic Fungi & Roots/G & $\begin{array}{l}\text { saprophytes, parasitic } \\
\text { on fungi }\end{array}$ \\
\hline Umbelopsis sp. & Zygomycetes & Roots/F & $\begin{array}{l}\text { endophytes, } \\
\text { saprophytes }\end{array}$ \\
\hline Verticillium sp. & Anamorphic Fungi & Leaf litter/G and $\mathrm{F}$ & $\begin{array}{l}\text { plant pathogens, } \\
\text { parasitic on fungi }\end{array}$ \\
\hline Xylaria sp. & Ascomycetes & Leaf litter/G & decomposers \\
\hline
\end{tabular}

\footnotetext{
${ }^{1} \mathrm{~F}=$ Torreya State Park, Florida; G = Decatur, Georgia.
} 
$\stackrel{\sim}{\sim}$

*

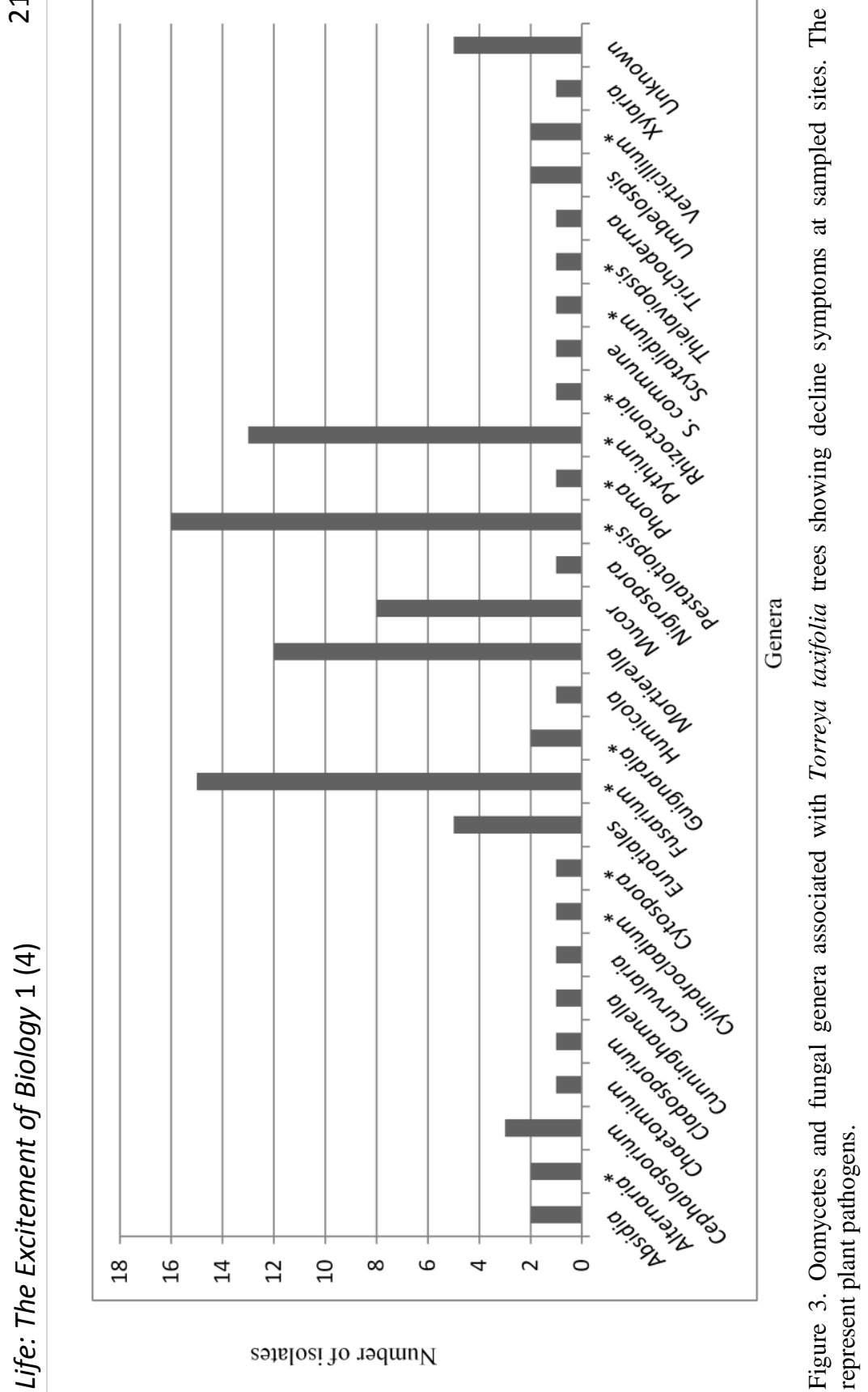


Other fungi isolated using Torreya leaves as baits were Absidia sp. (Zygomycetes) and Cladosporium sp. (Anamorphic fungi). Fungi such as Pestalotiopsis microspora, Fusarium spp., Rhizoctonia spp., Pythium sp., in addition to an unknown Oomycetes, other than Phytophthora spp., were isolated directly from mycelia observed on bark associated to plant litter surrounding tree's base (Figure 4).

Alternaria spp., Cylindrocladium sp., Fusarium spp., Phoma sp., Pythium spp., Rhizoctonia sp., Thielaviopsis sp. and Verticillium sp. are among soil-borne fungal species identified (Figures 3 and 4). To our knowledge none of these soilborne pathogens have been shown to cause disease in T. taxifolia roots (Alfieri 1984, El-Gholl 1985, USFWS 1986, Alfieri et al. 1987, Schwartz et al. 1996). Pestalotiopsis spp. was the most common genera isolated during this study, associated to bark, plant litter and necrotic roots at both locations, Florida and Georgia (Figure 3). Fusarium torreyae, Pestalotiopsis microspora and Scytalidium sp., have been shown to cause needle spots and stem cankers in $T$. taxifolia (Hermann and Schwartz, 1997; Schwartz et al., 1996; Smith et al. 2011). Another plant pathogen, Phoma spp. was found associated to Torreya's roots in Georgia. Some species have been associated and shown pathogenic to woody plants (Boerema et al. 2004).

In this study, various Fusarium species (anamorph of Gibberella spp.) were isolated in both locations from roots and associated to bark, plant litter and dying trees. From Georgia, Fusarium oxysporum was isolated from roots and plant litter. This species has been associated with seedling death and with root rot in Pinus and Eucalyptus seedling in South Africa (Viljoen et al. 1992). Fusarium solani was also isolated from roots of dying trees at this site (Table 3). Based on macroconidia and chlamydospores morphology, none $F$. torreyae was isolated during this study (Aoki et al. 2013). Recently this species have been shown to cause Torreya canker disease in Florida (Smith et al. 2011). DNA analysis of the ITS rDNA region showed that Fusarium spp. isolated during this study were closed to $F$. subglutinans, $F$. oxysporum and Gibberella spp. clades (Figure 5). However, amplification of other more informative genetic regions such as RNA polymerase largest subunit (RPB1 and RPB2) was not employed during this study.

Other plant pathogens identified by DNA analysis were: Cytospora sp., Guignardia spp. and Umbelopsis sp. (Figure 6). Cytospora canker has been reported in shrubs and trees in Colorado (Jacobi 2009). Guignardia is a genus that includes endophytes as well as important foliar pathogens (Peres et al. 2007). Umbelopsis spp. are zygomycetes that has been reported as endophytes of root xylem tissue of healthy conifers in the state of Washington, USA (Hoff et al. 2004). 


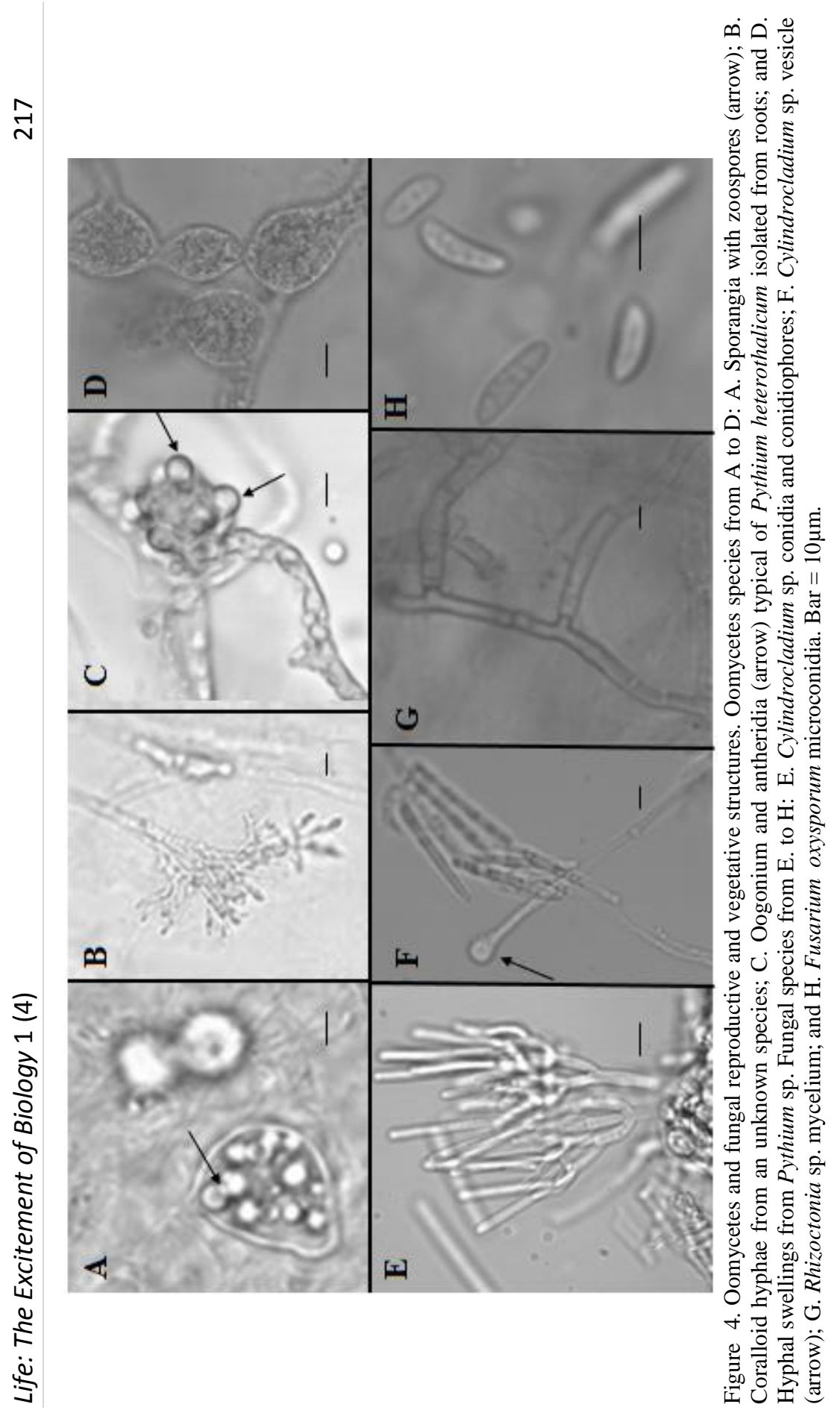




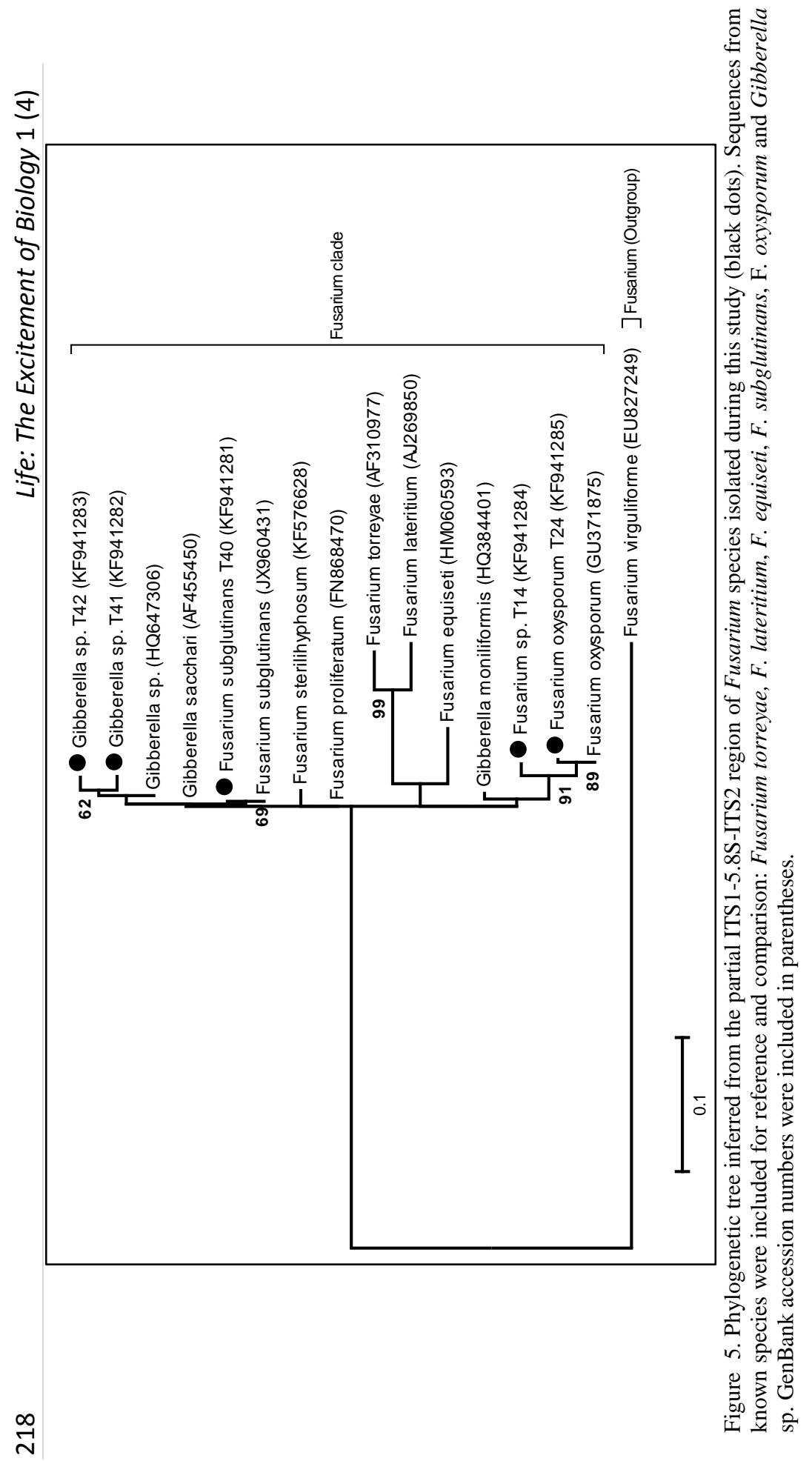


$\stackrel{2}{7}$

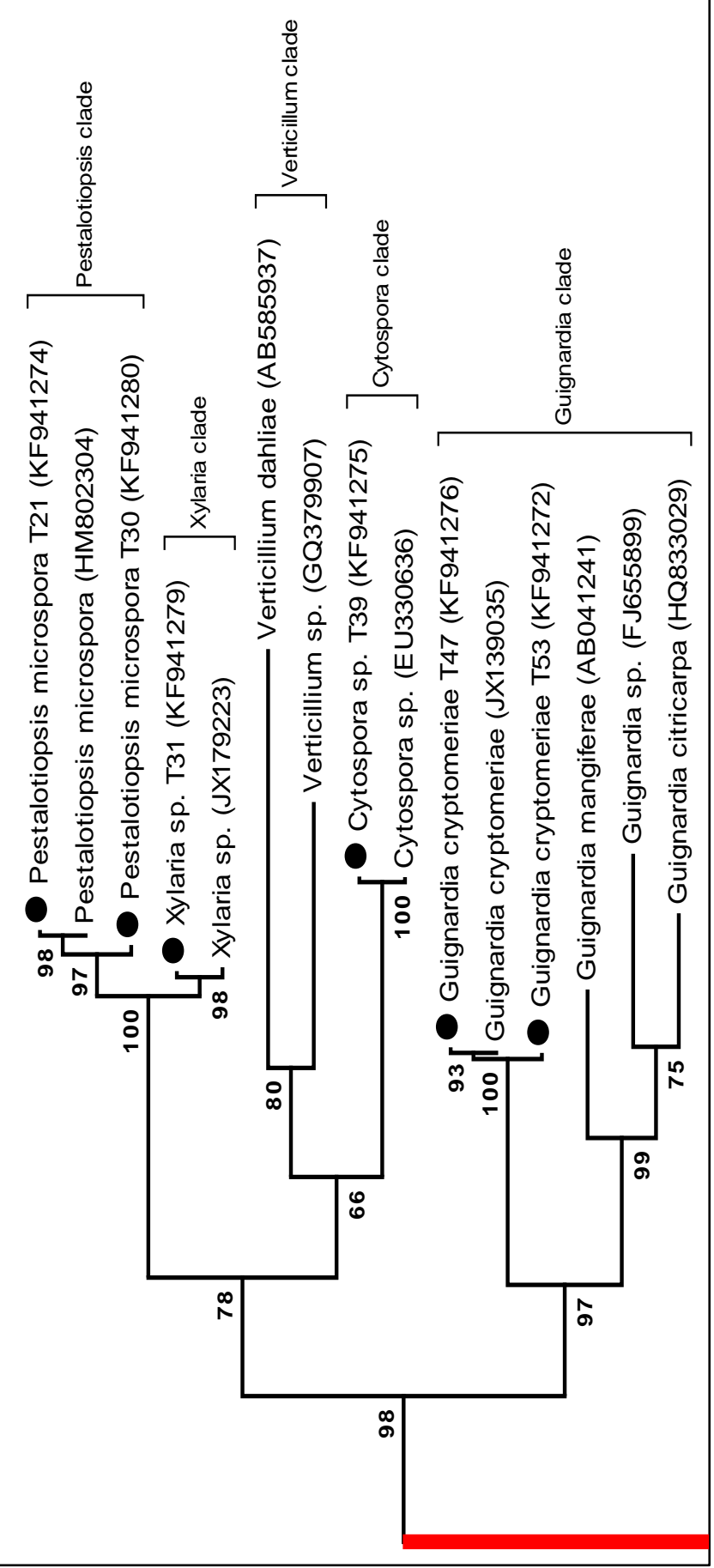




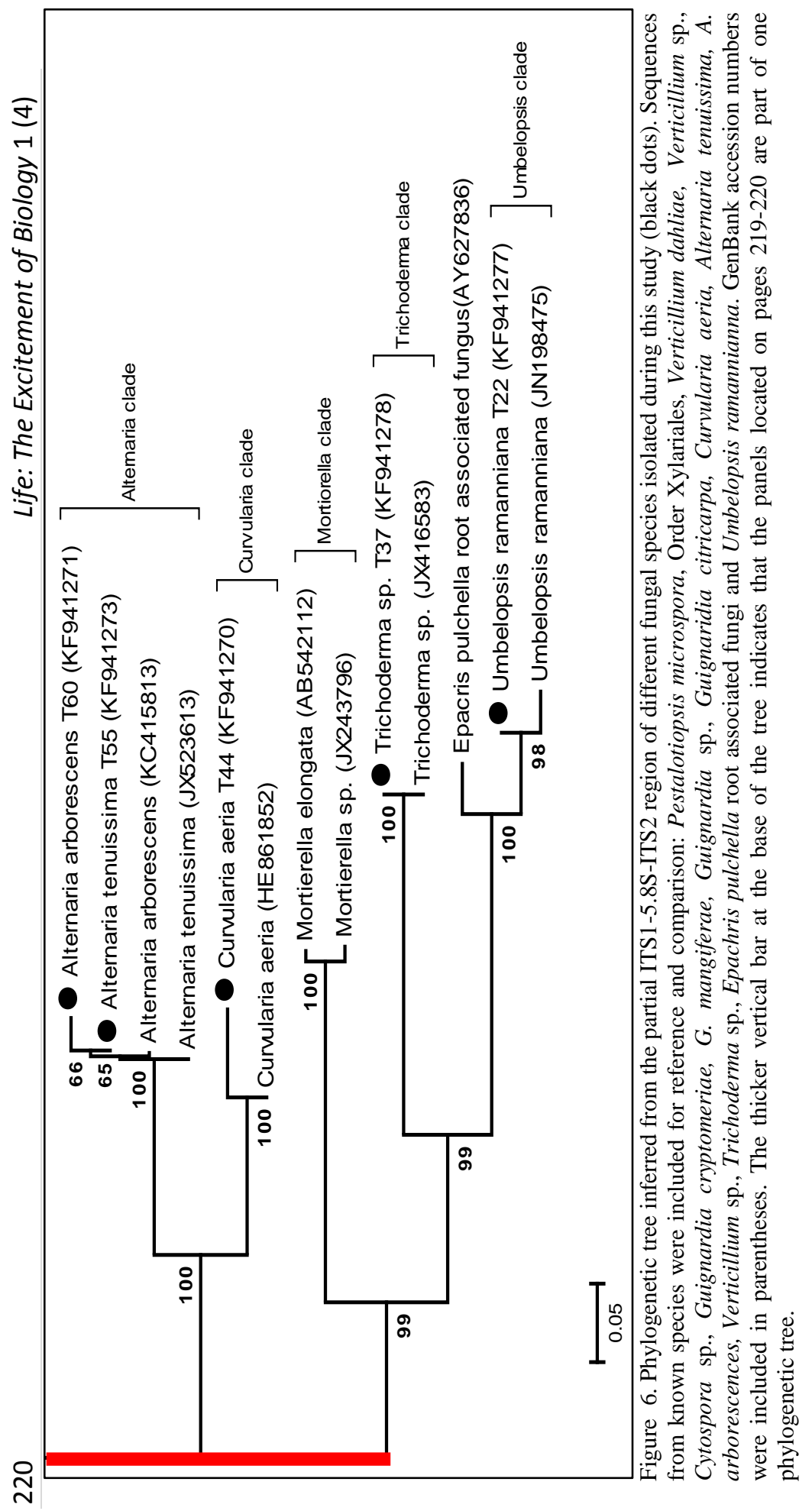


These results suggest that fungi inhabiting the soil and rhizophere of $T$. taxifolia are diverse and some species could play an important role in its decline. Nevertheless, fungal identification is problematic due to the enormous, largely unexplored diversity and the need of accurate annotated reference DNA sequences. Research related to environmental samples revealed that the vast majority of the microbial diversity (99\%) is missed by cultivation-based methods that we traditionally used (Riesenfeld et al. 2004). Concepts such as metagenomics, describes the functional and sequence-based analysis of the collective microbial genomes contained in an environmental sample (Riesenfeld et al. 2004). That is why non-culturable microbial communities which inhabit soils are define as the most complex known to science, and poorly understood despite their economic importance (Riesenfeld et al. 2004). Thus further research is needed using metagenomic technology to understand the dynamics of the microbial interactions related to $T$. taxifolia in the forest. Another very important consideration relates to the plant itself, one is the difficulty to germinate $T$. taxifolia seeds. Seedlings with healthy root systems are necessary to conduct pathogenicity tests and to complete Koch's postulates, crucial to demonstrate the role of some of the species as root pathogens. Another challenge that should be considered are the restrictions to obtained plants of a plant species that is federally listed as endangered to performed experiments.

\section{Acknowledgments}

This research was supported by Fish and Wildlife Service Panama City, Florida, contract number 401818M964 and NIFA HSI USDA grant number 2012-01871. Thanks are expressed on behalf of the authors to Ms. Tova Spector former biologist with the Department of Environmental Protection, Panama City, Florida, for her help locating specimens during the survey at the Torreya State Park, Floeida, to the U.S. Army Corps of Engineers, Decatur, Goergia, and to volunteers that helped during the survey at tracts in Decatur, GA.: Dave, Alan and Katharina Gorchov. Thanks are expressed on behalf of the authors to Ms. Luz M. Serrato for her laboratory assistance and to Ag. Eng. Jorge D. Caicedo for his assistance with DNA sequence data. Mention of firms' names or trade products does not imply their endorsement by UPR, USDA, or the FWS.

\section{Literature Cited}

Agrios, G. N. 2005. Plant Pathology. Fifth Edition. Elsevier Academic Press. New York, NY, USA. $922 \mathrm{pp}$.

Alfieri, S. A. Jr., K. R. Langdon, C. Wehlburg, and J. W. Kimbrough. 1984. Index of plant diseases in Florida. Florida Department of Agriculture and Consumer Services. Division of Plant Industry. Bulletin 11. p. 380.

Alfieri, S. A. Jr., C. L. Schoulties, K. R. Langdon, and N. E. El-Gholl. 1987. Leaf and stem disease of Torreya taxifolia in Florida. Florida Department of Agriculture and Consumer Services. Division of Plant Industry. Plant Pathology Circular No. 291. 4 pp.

Barnard, E. L., G. M. Blakeslee, J. T. English, S. W. Oak, and R. L. Anderson. 1985. Pathogenic fungi associated with sand pine root disease in Florida. Plant Disease 69:196-199. http://dx.doi.org/10.1094/PD-69-196

Barnett, H. L. and B. B. Hunter, 1998. Illustrated Genera of Imperfect Fungi. Fourth Edition. American Phytopathological Society. St. Paul, Minnesota, USA. 218 pp.

Boerema, G. H., J. de Gruyter, M. E. Noordeloos, and M. E. C. Hamers. 2004. Phoma Identification Manual: Differentiation of Specific and Infra-specific Taxa in Culture. CABI Publishing. Wallingford, Oxfordshire, UK. 470 pp. 
Christenhusz, J. M. M., J. L. Reveal, F. G. Martin, R. M. Robert, and W. M. Chase. 2011. Linear sequence, classification, synonymy, and bibliography of vascular plants: Lycophytes, ferns, gymnosperms and angiosperms. Phytotaxa 19: 1-134.

El-Gholl, N. E. 1985. Fusarium lateritium causing needle spots on Torreya taxifolia in Florida. Plant Disease 69:905. http://dx.doi.org/10.1094/PD-69-905a

Farr, D. F., G. F. Bills, G. P. Chamuris, and A.Y. Rossman. 1989. Fungi on plants and plant products in the United States. APS Press. St. Paul, Minnesota, USA 1252 pp.

Ferguson, A.J. and Jeffers, S.N. 1999. Detecting Multiple Species of Phytophthora in Container Mixes from Ornamental Crop Nurseries. Plant Disease 83: 1129-1136. http://dx.doi.org/10.1094/PDIS.1999.83.12.1129

Gallegly, M. E. and C. Hong. 2008. Phytopthora: Identifying species by morphology and DNA Fingerprints. APS Press. St Paul, Minnesota, USA. 158 pp.

Geiser, D. M., M. M. Jimenez Gasco, S. Kang, I. Makalowska, N. Veeraraghavan, T. Ward, N. Zhang, G. A. Krildau, and K. O'Donnell. 2004. Fusarium-ID v.1.0: A DNA sequence database for identifying Fusarium. European Journal of Plant Pathology 110: 473-479. http://dx.doi.org/10.1023/B:EJPP.0000032386.75915.a0

Hanlin, R. T. 1990. Illustrated Genera of Ascomycetes. Volume I. APS Press. St Paul, Minnesota, USA. 263 pp.

Hendrix, F. F. and W.A Campbell. 1973. Pythium as plant pathogens. Annual Review of Phytopathology 11:77-98. http://dx.doi.org/10.1146/annurev.py.11.090173.000453

Herman, S. M. and M. W. Schwartz. 1997. Studies on the population biology and pathogens of Torreya taxifolia Arn. Final Report to Florida Division of Forestry (Tallahassee, Florida, USA). $15 \mathrm{pp}$.

Hodges C. S. and L. C. May. 1972. A root disease of pine, Araucaria, and Eucalyptus in Brazil caused by a new species of Cylindrocladium. Phytopathology 62: 898-901. http://dx.doi.org/10.1094/Phyto-62-898

Hoff, J. A., N. B. Klopfenstein, G. I. McDonald, J. R. Tonn, M.-S. Kim, P. J. Zambino, P. F. Hessburg, J. D. Rogers, T. L. Peever and L. M. Carris.2004. Fungal endophytes in woody roots of Douglas-fir (Pseudotsuga menziesii) and ponderosa pine (Pinus ponderosa). Forest Pathology 34 (2004) 255-271. http://dx.doi.org/10.1111/j.1439-0329.2004.00367.x

Inglis, C. and F. Hill. 2007. Sampling soil for pathogens of trees and shrubs. Forest Health News No. 177. MAF Biosecurity New Zealand. Plant Health and Environment Lab. IDC, Tamaki. Auckland, New Zeland. www.nzffa.org.nz/farm-forestry-model/

Jacobi, W. R. 2009. Cytospora Canker. Extension Fact Sheet No. 2.937. Colorado State University. Fort Collins, Colorado, USA. 2 pp.

Jeffers, S. N., and Martin, S. B. 1986. Comparison of two media selective for Phytophthora and Pythium species. Plant Diseases 70:1038-1043. http://dx.doi.org/10.1094/PD-70-1038

Leslie, J. F. and B. A. Summerell. 2006. The Fusarium Laboratory Manual. Blackwell Publishing, Oxford, England, UK. 388 pp. http://dx.doi.org/10.1002/9780470278376

Lombard, L., C. A. Rodas, P. W. Crous, B. D. Wingfield and M. J. Wingfield. 2009. Calonectria (Cylindrocladium) species associated with dying Pinus cuttings. Persoonia 23:41-47. http://dx.doi.org/10.3767/003158509X471052

Lombard, L., X. D. Zhou, P. W. Crous, B. D. Wingfield, and M. J. Wingfield. 2010. Calonectria species associated with cutting rot of Eucalyptus. Persoonia 24:1-11. http://dx.doi.org/10.3767/003158510X486568

Mitchell, D.J. and M.E. Kannwischer-Mitchell. 1992. Phytophthora. In,Methods for Research on Soilborne Phytopathogenic Fungi. pp: 31-38. Eds. L.L. Singleton, J.D. Mihail and C.M. Rush. American Phytopathological Society (APS) Press. Saint Paul, Minnesota, USA. 265 pp.

Mount, L.L. and J.A. Smith. 2010. Identification of the Florida torreya canker pathogen. Phytopathology 100: S174.

Penn, O., E. Privman, H. Ashkenazy, G. Landan, D. Graur, and T. Pupko. 2010. GUIDANCE: a web server for assessing alignment confidence scores. Nucleic Acids Research 38: W23-W28. doi: 10.1093/nar/gkq443

Peres, N. A., Harakava, R., Carroll, G. C., Adaskaveg, J. E., and Timmer, L. W. 2007. Comparison 
of molecular procedures for detection and identification of Guignardia citricarpa and G. mangiferae. Plant Diseases 91:525-531. http://dx.doi.org/10.1094/PDIS-91-5-0525

Reeser, P. W., W. Sutton, and E. M. Hansen, 2008. Phytophthora species causing Tanoak Stem Cankers in Southwestern Oregon. Plant Disease 92(8):1252. http://dx.doi.org/10.1094/PDIS92-8-1252B

Riesenfeld, C. S., P. D. Schloss, and J. Handelsman. 2004. METAGENOMICS: Genomic analysis of microbial communities. Annual Review of Genetics 38:525-552. http://dx.doi.org/10.1146/annurev.genet.38.072902.091216

Rizzo, D. M., Garbelotto, M., Davidson, J. M., Slaughter, G. W., and Koike, S. T. 2002. Phytophthora ramorum as the cause of extensive mortality of Quercus spp. and Lithocarpus densiflorus in California. Plant Disease 86:205-214. http://dx.doi.org/10.1094/PDIS.2002.86.3.205

Schwartz, M. W., S. M. Hermann, C. S. Vogel. 1995. The catastrophic loss of Torreya taxifolia: assessing environmental induction of disease hypotheses. Ecological Applications 5 (2):501516. http://dx.doi.org/10.2307/1942039

Schwartz, M. W., S. M. Hermann, and P. J. van Mantgem. 2000. Estimating the magnitude of decline of the Florida torreya (Torreya taxifolia Arn.). Biological Conservation 95: 77-84. http://dx.doi.org/10.1016/S0006-3207(00)00008-2

Smith, J. A., K. O'Donnell, L. L. Mount, K. Shin, K., Peacock, A. Trulock, T. Spector, J. CruseSanders, and R. Determann. 2011. A novel Fusarium species causes a canker disease of the critically endangered conifer, Torreya taxifolia. Plant Disease 95:633-639. http://dx.doi.org/10.1094/PDIS-10-10-0703

Tamura K., D. Peterson, N. Peterson N, G. Stecher, M. Nei M, and S. Kumar, 2011. MEGA5: Molecular Evolutionary Genetics Analysis using Maximum Likelihood, Evolutionary Distance, and Maximum Parsimony Methods. Molecular Biology and Evolution 28: 27312739. http://dx.doi.org/10.1093/molbev/msr121

U.S. Fish and Wildlife Service. 1986. Florida torreya (Torreya taxifolia) recovery plan. U.S. Fish and Wildlife Service. Atlanta, Georgia, USA. 42 pp.

van der Plaats-Niterink, J. 1981. Monograph of the genus Pythium. Studies in Mycology. No. 21. 244 $\mathrm{pp}$.

Viljoen, A., M. J. Wingfield, and P. W. Crous. 1992. Fungal pathogens in Pinus and Eucalyptus seedling nurseries in South Africa: a review. South African Forestry Journal 161: 45-51. http://dx.doi.org/10.1080/00382167.1992.9630424

Watanabe, T. 1988. Kinds and distribution of Pythium species isolated from soils in Shikoku Island. Annals of the Phytopathological Society of Japan 54:523-528. http://dx.doi.org/10.3186/jjphytopath.54.523

White, T. J., T. Bruns., S. Lee., J. W. Taylor. 1990. Amplification and direct sequencing of fungal ribosomal RNA genes for phylogenetics. pp. 315-322. In, PCR Protocols: A guide to methods and applications. Innis, M. A., D. H. Gelgard, J. J. Snisky, and T. J. White (Editors). Academic Press. New York, NY, USA. 482 pp. 